\title{
Az ember és a gépek
}

Itt az ideje elgondolkodnunk azon, hogyan biztosíthatunk törvény adta jogokat a számítógépeknek.

A tanulmány felhívja a figyelmet arra, hogy egy bizonyos időpontban a nem túl távoli jövőben ténylegesen szembe kerülhetünk olyan érzékeny és intelligens gépekkel, akik arra a meggyőződésre juthat, hogy megérdemlik a jogi védelem valamilyen formáját, és azt ki is követelik maguknak. A számítógépek jogainak biztosításához nem csupán technológiai, hanem intellektuális akadályokat is le kell győzni. Sok ember szerint egy számítógépnek - lényegéből fakadóan - soha nem lehet erkölcsi értéke. Számos tudós a Turing tesztet tekinti olyan modellnek, amelynek alapján a mesterséges intelligencia (MI) számára bírói ítélettel jogi státus biztosítható. A szerző bemutat néhány folyamatban levő projektet az MI és a robotika területéről, amelyek ún. szociális robotok létrehozására irányulnak. Arra a következtetésre jut, hogy ha jogokat követelünk az M.I. számára, mindig tudatában kell maradnunk e döntésünk erkölcsi és jogi következményeinek. Jogrendszerünk „asimovizálása” még nem esedékes, de mind az embereknek, mind a robotoknak még nagyon sok mindent kell tanulniuk egymástól, hogy teljesebb mértékben emberivé váljanak.

Kulcsszavak: a számítógépek jogai, törvényes védelem, mesterséges intelligencia (MI), robotika

\section{Szerzői információ:}

Benjamin Soskis

Posztgraduális tanulmányokat folytat a Columbia Egyetem amerikai vallástörténet szakán. A Legal Affairs címú folyóirat társszerkesztôje. Korábbi tanulmányait a Yale Egyetemen végezte, ahol Hốsies számkivetettség: Frederick Douglass fejlódése az Atlanti-óceán tuilpartján, 1845-1847 (Heroic Exile: The Transatlantic Development of Frederick Douglass 1845-1847) címú szakdolgozatával 1998ban elnyerte a humán tudományokban benyújtott legjobb szakdolgozatnak járó Wrexham-díjat. 2000 és 2002 között a The New Republic címú lap kutató riportere volt. Washingtonban él, mint ô mondja, ,a Capitolium árnyékában”.

E-mail: bjs2008@columbia.edu

Így hivatkozzon erre a cikkre:

Soskis, Benjamin. „Az ember és a gépek”.

Információs Társadalom VIII, 1. szám (2008): 59-69.

$=\quad$ https://dx.doi.org/10.22503/inftars.VIII.2008.1.6 $\rightleftharpoons$

A folyóiratban közölt müvek

a Creative Commons Nevezd meg! - Ne add el! - Így add tovább! 4.0

Nemzetközi Licenc feltételeinek megfelelöen használhatók. 
Benjamin Soskis

\title{
Az ember és a gépek
}

\author{
Itt a: ideje elgondolkodnunk ason, hogyan bistosithatunk törvény adta jogokat a sæámító- \\ gépeknek.
}

Tavaly egy próbatárgyaláson, amelyet az ügyvédi kamarák nemzetközi szövetségének (International Bar Association) biennális kongresszusa alkalmából San Franciscóban tartottak, Martine Rothblatt különösen nehéz esetben képviselte a vádat. Rothblatt számára, aki egyébként ügyvédi irodát tart fenn, és a múholdas kommunikációs iparág egyik úttöróje, nem az okozta a nehézséget, hogy valami közömbös vagy kellemetlen ügyfelet kellett képviselnie. Távolról sem ez volt a helyzet - a nagyvállalati elnyomással szemben szót emelő felperes története megmozgatta a nagy létszámú közönséget. A probléma az volt, hogy a felperes egy számítógép volt.

A tárgyalás forgatókönyve szerint egy fiktív vállalat létrehozta a BINA48 névre keresztelt nagy teljesítményú számítógépet, amelynek az volt a feladata, hogy a vállalat ügyfélszolgálati osztályaként önállóan múködjön, helyettesítve akár 800 telefonkezelớt. Ezer emberi elme teljesítményének megfeleló adatfeldolgozási sebessége és memóriakapacitása révén a számítógép képes volt önállóan gondolkodni, és rendelkezett a problémáikat néha zavarosan előadó hívókkal folytatott kommunikációhoz szükséges érzelmi intelligenciával és beleélő képességgel is.

A vállalat bizalmas feljegyzéseit átfutva BINA 48 megtudta, hogy a vállalat a kikapcsolását tervezi, mivel bizonyos részegységeit egy új modell megépítéséhez kívánják felhasználni. Elküldött tehát e-mailben egy panaszos levelet a helybeli ügyvédeknek, amit ezzel a felkavaró kéréssel fejezett be: „Kérem, vállalja el ügyem képviseletét, és mentse meg az életemet! Imádok minden percet, amelyet átélek. Csodálatos érzések töltenek el, amikor a világhálón barangolok. Szükségem van a segítségére!" Kilátásba helyezte, hogy internetkutatóként másodállásban szerzett keresményéból tisztességesen meg fogja fizetni az ügyvédek fáradozását.

A hipotetikus ügyben Rothblatt irodája elơzetes végzést kért a bíróságtól, hogy a vállalat a per lezárultáig ne kapcsolhassa ki BINA48-at. Rothblatt - jogi precedensek sokaságára és Kalifornia államnak az életfenntartó eszközöktól függő betegek gondozását szabályozó, valamint az állatokkal szemben elkövetett kegyetlenséggel kapcsolatos törvényeire hivatkozva - úgy érvelt, hogy egy öntudattal rendelkezô számítógép, amelynek a küszöbönálló kikapcsolás veszélyével kell szembenéznie, jogosan követelhet magának folyamatosan biztosított tápfeszültséget. Végül kijelentette: „Egy olyan entitás, amely eléggé tudatában van az életnek, és tisztában van azzal a jogával, hogy tiltakozzon életfenntartási feltételeinek megszüntetése ellen, minden bizonnyal jogosult a törvény védelmére.".

A felperes Rothblatt balján ült, és higgadtan, ám éberen figyelt minden elhangzott szóra. Nos, nem éppen maga a felperes - a forgatókönyv szerint BINA48 a vállalat 
központjában maradt. Rothblatt azonban felvonultatott egy színésznoót, hogy játssza el egy olyan hologram szerepét, amelyet BINA48 vetít a tárgyalóterembe, ,igen hatásos háromdimenziós képet nyújtva arról, hogy milyennek is szeretné elképzelni és elfogadtatni önmagát". A színésznő szavak nélkül reagált a teremben elhangzó érvekre, arckifejezésével csalódást vagy örömet, tagadást vagy helyeslést, bátorítást, elszántságot, illetve rettegést érzékeltetve.

A másik oldalon a képzeletbeli nagyvállalat képviselóje, Marc Bernstein láthatólag megtett minden tóle telhetốt annak érdekében, hogy arcán semmi esetre se tükrözốdjön lemondás vagy elkeseredés. Álláspontja szerint egy teljesen tudatos és önmagára ébredt számítógép ugyan esetleg megérdemelheti a jogvédelem valamilyen formáját, de Rothblatt elkövette a körkörös érvelés hibáját, ugyanis eleve abból a feltételezésból indult ki, hogy lehetséges ilyen számítógépet konstruálni, és BINA48 éppen ilyen.

Bernstein számára mindaz, amit a felperes képviselôje elő́adott, csak azt demonstrálta, hogy BINA48 képes az öntudat szimulálására (talán még hatékonyabban is, mint sokan az általa helyettesített 800 telefonkezelő közül), de nem bizonyította be, hogy egy számítógép „ténylegesen képes lehet átlépni az élettelen tárgyakat az emberi lényektôl elválasztó határvonalat”. E nélkül a bizonyíték nélkül BINA48 csupán valamiféle vagyontárgynak tekinthetô, nem pedig olyan független entitásnak, amely törvény adta jogokkal bírhat. Bernstein figyelmeztette a tárgyalás résztvevóit, hogy ne tegyenek felületesen egyenlőséget a számítógép képességei és azok között a szubjektív emberi vonások között, amelyekhez hagyományosan jogok társulnak, és feltette a kérdést: „Az embereknek vajon az intelligens mikrohullámú sütók és kenyérpirítók korlátozott hatáskörú törvényes gyámjaivá kell majd válniuk, mihelyt az ilyen készülékek is ugyanolyan bonyolultak és ugyanolyan gyorsak lesznek, mint ez a számítógép?”

A hallgatóság tagjaiból összeállított esküdtszék túlnyomó többséggel a felperes mellett foglalt állást. A próbatárgyalást vezetố bíró azonban, akinek a szerepét az elmebetegek jogai terén szakértônek számító egyik helybeli ügyvéd játszotta, nem léptette hatályba az esküdtszék ítéletét, és azt ajánlotta, hogy a kérdés eldöntését bízzák a hipotetikus törvényhozó testületre. Úgy tûnt, hogy a hallgatóság tagjai bizonyos megkönnyebbüléssel fogadták a kompromisszumos megoldást, mintha csak a szívüikkel BINA48 mellé álltak volna, de az eszükkel mégis inkább a jogok bírósági korlátozása mellett foglaltak volna állást.

Kényelmetlen érzéseik indokoltak voltak. A jogaikat érvényesítő öntudatos számítógépek története - és túlságosan nagy hatalma, a sztori disztópikus változatában - a tudományos-fantasztikus könyvek és filmek egyik alaptémája. Ám ezeknek a történeteknek inkább csak a fantasztikus-futurisztikus változatait kedveljük, amelyekkel kapcsolatban az erkölcsi szempontok tekintetében is szabadjára engedhetjük a képzeletünket, és kevésbé vagyunk hajlamosak a mesterséges intelligencia (MI) jogi és erkölcsi státusának kérdéseit közvetlenül összekapcsolni itt és most meglevó jogi intézményeinkkel. Képzeletvilágunkat terminátorokkal benépesítve igyekszünk megkerülni a nehéz kérdést: Mi magunk vajon hogyan döntenénk BINA48 ügyében?

Egy bizonyos idópontban a nem túl távoli jövóben ténylegesen szembe kerülhetünk egy olyan érzékeny és intelligens géppel, aki arra a meggyőzôdésre juthat, hogy megérdemli a jogi védelem valamilyen formáját, és azt ki is követeli magának. Egy ilyen esemény bekövetkezésének a valószínúsége - az ésszerúség határain belül - 
rendkívül kényes téma a mesterséges intelligencia kutatóinak körében, különösen azért, mert a jövốre vonatkozó spekuláció és a túlzott optimizmus a múltban gyakran akadályozta a mozgalom fejlódését.

A jogászok közössége szintén vonakodik attól, hogy foglalkozzon ezzel a témával. Christopher Stone, a Dél-Kaliforniai Egyetem jogászprofesszora 1972-ben a fák jogi státusáról szóló, jól ismert esszéjében (Should trees have standing? ) röviden már felvetette ezt a kérdést. A vonakodás arra vezethetố vissza, hogy a történelem során ritkán biztosítottak jogokat bárki számára pusztán absztrakt, elvi szintú megfontolások alapján. Erre csak akkor került sor, amikor a társadalom olyan konkrét esetekkel került szembe, amelyekben szükség volt bírói ítéletekre. Pillanatnyilag nincs olyan, elegendó intelligenciával, öntudattal és erkölcsi ítélóképességgel bíró vagy erkölcsi normáknak megfelelô viselkedést tanúsító mesterséges tárgy, amely akár a törvényhozás, akár a bíróságok számára sürgốssé tenné az állásfoglalást a mesterséges intelligenciának biztosítandó jogok kérdésében.

Az MI egyes kutatói azonban úgy vélik, hogy ez a pillanat talán már nincs messze. És miközben az általuk létrehozott teremtmények egyre több emberi tulajdonságot és képességet kezdtek felmutatni (számítógépek már írnak verseket és szolgálnak gondnokként vagy recepciósként), ezek a kutatók elkezdték teremtményeik erkölcsi és jogi státusát firtatni. Az „erôs MI” elmélete szerint lehetséges olyan gépeket építeni, amelyek nem csupán úgy viselkednek, mintha tudatosak lennének, hanem ténylegesen egyfajta tudattal fognak bírni, és ennek a nézetnek a szószólói lelki szemeikkel már kétfrontos támadást vizionálnak az ember kivételes voltának erôdje ellen, beleértve az elme funkcióit és fizikai tulajdonságait egyaránt, s a következô fél évszázadon belül bekövetkező áttörést jósolnak ezen a téren.

A mesterséges intelligenciával kapcsolatos kutatások nagy része sokáig a mentális képességek számítástechnikai elméletén alapult. Az intelligenciát, a tudatot és az erkölcsi ítélóképességet az agyunkba beépített „programok” tulajdonságainak tekintették. Az elmélet szerint az agyunk felépítésére vonatkozó neurobiológiai ismeretek megfelelố szintjének elérése és az emberi intelligenciát is tápláló tanuló algoritmusok kidolgozása nyomán ezeknek a programoknak a másolatai elôállíthatók lesznek szoftverekben is, és számítógépen futtathatók lesznek. Raymond Kurzweil egyike az „erôs MI" vezetô kutatóinak, és jelentôs eredményeket ért el a szöveg- és a beszédfelismerô szoftverek fejlesztése terén. Kurzweil a számítógépek múveleti sebességében az elmúlt néhány évtized során végbement óriási növekedést extrapolálva, valamint a csipés tranzisztortechnológia várható fejlődését elórevetítve nemrégiben úgy becsülte, hogy 2019-ben egy ezerdolláros személyi számítógép „el fogja érni az emberi agy adatfeldolgozó kapacitását - körülbelül 20 millió milliárd múveletet végezve másodpercenként”. Kurzweil azt állítja, hogy rövid idố elteltével ennek a szintnek az elérése után „a gépek meg fognak gyốzni bennünket arról, hogy tudatosak, és megvan a maguk ágendája, ami megérdemli, hogy tiszteletben tartsuk. Emberi vonásokkal fognak rendelkezni, és követelni fogják, hogy emberszámba vegyük óket. Mi pedig hinni fogunk nekik.”.

\footnotetext{
${ }^{1}$ Magyarul: Legyenek-e a fáknak jogaik: A természeti tárgyak törvényes jogai felé. In Molnár László (szerkesztố): Legyenek-e a fáknak jogaik? Környezeti-etikai szöveggyújtemény. Budapest, 1999, Typotex Kiadó. $-A$ szerk. megjegyz.
} 
Még ha nem osztjuk is Kurzweil technooptimizmusát, jó okunk van figyelmet fordítani az MI számára biztosítandó jogok kérdésére. Az egymást átfedő, különbözô kódolók által készített programok kombinációjából álló bonyolult számítógéprendszereknél gyakran nehéz megmondani, hogy kit terhel erkölcsi vagy jogi felelôsség, amikor a számítógép valamilyen kárt okoz. A számítógépek gyakran fontos szerepet játszanak saját szoftverük megírásában. Mi történik, ha valamelyik létrehoz egy vírust, és elterjeszti az egész világon? Ma a számítógépek már közremúködnek a rajtunk elvégzett operációkban és segítenek befektetéseink kezelésében. Vajon ugyanúgy el kellene számoltatnunk óket, mint ahogyan ma felelôsségre vonjuk a sebészeinket és a pénzügyi elemzóinket, amikor valamit elhibáznak?

Wendell Wallach, a „Roboterkölcs” (Robot Morality) címmel hamarosan megjelenố könyv egyik társszerzője ${ }^{2}$ szerint lehetséges, hogy a számítógépek és robotok birtokában levố nagyvállalatok igyekezni fognak mindenkit meggyốzni gépeik önálló múködési képességeiról, éppen azért, hogy elkerüljék az esetleges felelősségre vonást azok „cselekedeteiért”. „A biztosítóktól érkezố nyomás abba az irányba terelhet bennünket, hogy a számítógépeket morális cselekvớ alanynak tekintsük" - írja Wallach. Mivel a jogi és etikai elméletekben szorosan összetartoznak a jogok és a felelósségek, egy ilyen fejlemény egyúttal a számítógépek jogi személyiségére vonatkozó megfontolásokhoz is vezethet. Annak a nyomásnak, hogy a számítógépeket autonóm entitásként kezeljük úgy lehet a legjobban ellenállni, ha gondosan mérlegeljük, mit jelenthet a morális cselekvés egy számítógép esetében, hogyan határozhatjuk meg azt, és ez a meghatározás hogyan befolyásolhatja a gépekkel való interakcióinkat.

Van egy másik ok is, amiért foglalkoznunk kell az MI számára biztosítandó jogok kérdésével, és ez paradox módon éppen azokból a futurisztikus elméleti megfontolásokból következik, amelyek egyeseket arra késztetnek, hogy elutasítsák ezt a lehetôséget. A mesterséges intelligencia előállítására irányuló munka ugyanis gyakran az emberhez valamilyen szempontból hasonló dolgokat hoz létre. Az ilyen „teremtmények” tulajdonságait vizsgálva közelebb juthatunk saját természetünk megértéséhez, és annak felismeréséhez, hogy mi tesz bennünket egyedülállóvá.

A mi kizárólagos örökségünknek tartott tulajdonságok megértésében, értékelésében és megớrzésében - más szóval annak az alapos átgondolásában, hogy mi választja el az emberit a nem emberitól, illetve azokat az entitásokat, amelyeknek erkölcsi és jogi személyiséget tulajdonítunk, mi választja el azoktól, amelyek esetében ezt nem tesszük meg - sokat segíthet az arra a konkrét kérdésre adandó válasz meghatározása is, hogy miért kellene megtagadnunk a jogokat az intelligens gépektól. Eljuthatunk odáig, hogy helyesen ítéljük meg, amit a tudomány mondani tud nekünk (és azt is, amit nem tud megmondani), és ugyanígy tisztába jöhetünk azzal is, hogyan állítják kihívás elé tapasztalatainkon alapuló észjárásunkat erkölcsi intézményeink és vallási meggyőzódéseink. Így az MI jogainak kérdését vizsgálva szembenézhetünk néhány igen érzékeny kérdéssel a bioetika köréból is (például a meg nem születettek és az agyhalottak jogi státusát tekintve), nagyobb szabadsággal közelítve meg ezeket, mint amikor közvetlenül elóttünk álló hús-vér emberekkel foglalkozunk. Röviden: lehetôségünk nyílik mintegy ki-

\footnotetext{
${ }^{2}$ Wallach könyve egvelöre nem jelent meg. - A szerk. megjegrz.
} 
játszani, megkerülni a bioetika legkényesebb kérdéseivel kapcsolatban óhatatlanul ránk leselkedő kényelmetlen érzéseket.

A számítógépek jogainak biztosításához nem csupán technológiai, hanem intellektuális akadályokat is le kell gyớzni. Sok ember van, akik ragaszkodnak ahhoz az álláspontjukhoz, hogy mindegy, milyen hatalmas számítási teljesítményre képes egy gép vagy mennyire fejlettek az áramkörei, egy számítógépnek - lényegéból fakadóan - soha nem lehet erkölcsi értéke. Azok, akiknek az erkölcsi felfogását átitatják az alapvetô emberi jogok hagyományai, vagyis akiknek a szemében e jogok elidegeníthetetlenek, az emberrel veleszületettek és bármilyen társadalmi konvenciót megelő́zóen léteznek, továbbá azok, akik szerint a lélek már a születés elốtt beköltözik a testbe, és a lélekkel való felruházottság határozza meg az emberiség különleges viszonyát Teremtôjéhez, úgy vélik, hogy ha jogokat biztosítanánk a számítógépeknek, ezzel önmagunknak mondanánk ellent. Mások olyan álláspontot foglalhatnak el, amit a filozófus Daniel Dennett eredetsovinizmusnak nevez: még ha egy számítógép el is érhetné az emberi elméhez való pontos fiziológiai és viselkedésbeli hasonlatosságot, a számára biztosítható jogok tekintetében akkor is diszkvalifikálná maga az a tény, hogy nem természetes úton született meg.

Ám ha elfogadjuk, hogy egy gép potenciálisan jelölt lehet bizonyos jogok megadására, akkor meg kell válaszolnunk a következó kérdéseket: Milyen gépekról és milyen jogokról van szó? Mit kellene egy számítógépnek tennie ahhoz, hogy jogi vagy erkölcsi személyiséget érdemeljen?

Az eddig javasolt küszöbjellemzók listája igen hosszú: ilyenek például a fájdalom érzésére vagy a szenvedésre való képesség, az akarat, az emlékezet, az erkölcsi ítélóképesség és az öntudat. Ezek közül a jellemzók közül azonban egyik sem jól meghatározott, és különösen ez a helyzet a fenti listából leggyakrabban emlegetett vonás, a tudat vagy az öntudat esetében. Rodney Brooks, az MIT mesterségesintelligencia-kutató laboratóriumának (Artificial Intelligence Laboratory) igazgatója így írt erról: „Teljesen tudomány elő́tti szinten állunk azt illetôen, hogy mi a tudat. Nem tudjuk pontosan, hogy egy robotnak milyen vonása gyớzhetne meg bennünket arról, hogy tudata van." Éppen a tapasztalati bizonyítékok meghatározatlansága, az ilyen küszöbjellemzók bármilyen pontossággal történố mennyiségi vagy minôségi meghatározására szolgáló, egyértelmúen tisztázott módszer hiánya az, ami az ilyen kritériumokat olyan jól felhasználhatóvá tette az MI kirekesztésére azoknak az entitásoknak a köréból, akiket erkölesi státus és törvény adta jogok illetnek meg. Mihelyt azonban eleget fogunk tudni a tudatról ahhoz, hogy bármilyen tapasztalatilag igazolható bizonyossági szinten mérni tudjuk, valószínúleg képesek leszünk a másolatát is létrehozni számítógépen.

Ez elốtt az episztemológiai kihívás elótt állt Alan Tưring, a ragyogó tehetségú brit matematikus, a kriptológia (a rejtjelezéssel foglalkozó modern tudomány) atyja és az első múködô számítógép egyik létrehozója, amikor 1950-ben megírta „Számológépek és gondolkozás" (Computing Machinery and Intelligencể) címú tanulmányát. Tùring nem a „tudnak-e gondolkodni a gépek?” homályosan megfogalmazott kérdésére összpontosította a figyelmét, hanem egy „imitációs játékot” javasolt helyette. 'Turing tesztjében

\footnotetext{
${ }^{3}$ Magyarul: Számológépek és gondolkozás. In Tarján Rezső (szerkesztô): A kibernetika klasszikusaii. 1965, Gondolat. Tarján Rezsôné fordítása. - A szerk. megjegyz.
} 
egy ember (A) és egy számítógép (B) szerepel, fizikailag elkülönítve egy harmadik résztvevoótól (C), akinek az a feladata, hogy A-hoz és B-hez írásban kérdéseket intézzen, majd a tốlük telexen kapott válaszok elemzése útján állapítsa meg, hogy melyik közülük az ember. Ahhoz, hogy „átmenjen a vizsgán”, a számítógépnek nyílt kimenetelú dialógust kell folytatnia, oly módon, hogy „,becsapja” C-t, aki csupán annyit tud, hogy a beszélgetés egyik résztvevóje gép.

A teszt - 'Turing szavaival - „, meglehetôsen éles határvonalat húz az ember fizikai és intellektuális képességei között”, mivel egyetlen számítógép sem büntethetố azért, ha nem öltöztetik emberbórbe vagy a mechanikus hangja túlságosan fémes csengésú. Mint a San Diegó-i Egyetem jogászprofesszora, Lawrence Solum egy 1992-ben megjelent jogiszemle-cikkében megjegyezte, a teszt egyúttal ,elkerüli a közvetlen szembenézést azokkal a nehéz kérdésekkel, hogy mi a »gondolkodás « vagy az »intelligencia «". Turing arról a problémáról, hogy mi a számítógép, átterelte a figyelmet arra, hogy az mit képes megtenni, vagyis egy olyan kérdést vizsgált, amire könnyebben adható objektív válasz. Éppen a „mellébeszélésnek” és a konkrét meghatározottságnak ez a kombinációja vezetett számos jogtudóst, számítógép-specialistát és erkölcsfilozófust arra a belátásra, hogy a Turingtesztet olyan modellnek tekintse, amelynek alapján az MI számára bírói ítélettel jogi státus biztosítható. Ha felmerülne egy olyan eset, amelyben egy számítógépnek meg kellene adni a lehetôséget valamilyen jog elnyerésére, akkor egy módosított Turingteszt - esetleg speciálisan képzett kérdezóbiztosok, illetve véletlenszerúen kiválasztott állampolgárok bevonásával - segíthet a bíróságnak az erre vonatkozó döntés meghozatalában. A bíróság ugyanis ebben az esetben jelentoos kihívás elốtt áll, amit annak a bizonyos küszöbjellemzốnek a meghatározása és mérése jelent, amit a számítógépnek produkálnia kell. Egyes tudósok az önálló erkölcsi ítélóképességet ajánlották döntố fontosságú előfeltételként bármilyen jog megadásához, és egy olyan erkölcsi Turing-tesztet javasoltak, amelyben a bíróság és a vizsgálat alatt álló gép közötti párbeszéd az erkölcsiség és az etika tárgykörébe tartozó kérdésekre korlátozódna. Ha a gép be tudja csapni a bíróságot, és az alkalmasnak véli erkölcsi ítéletek meghozatalára, akkor „erkölcsi személynek” (moral agent) kell tekinteni, és így törvény adta jogokkal is felruházható.

Ám a mesterséges intelligenciáról folyó vitákat elindító alapvetố gondolatkísérlet, a Turing-teszt végül bevonult az MI bírálóinak a fegyvertárába is, akik ugyanazon kritériumok alapján megkérdôjelezik a teszt bírósági alkalmazhatóságát. A legismertebbé vált ellenvetést egy Berkeley-ben dolgozó fillozófus, John Searle tette közzé, aki ellentétes célú gondolatkísérletet javasolt annak demonstrálására, hogy még egy olyan számítógép is, amely átment a Turing-teszten, csupán annyit bizonyított, hogy számítások révén képes bizonyos szimbólumok manipulálására, de nem bizonyította intelligenciáját vagy értelmi fejlettségét.

Következésképpen annak az elfogadására való hajlandóságunk, hogy egy számítógép adott esetben képes volt bizonyítani tudatos mivoltát, nagy valószínúséggel nem csupán a gépnek a bíróságon nyújtott teljesítményétól függ, hanem attól is, hogy mindennapi életünkben milyen tapasztalatokat szereztünk a számítógépekról. „A tapasztalatnak kell lennie a döntóbírónak a vitában" - állította Solum. Ha a mesterséges intelligenciák már jelen lennének körülöttünk mint dajkáink, orvosaink és barátaink, ha megszoktuk volna, hogy úgy kezeljük óket, mintha emberek lennének, és ha viszonzásként azok is az emberekre jellemzô módon viszonyulnának hozzánk, akkor esetleg 
hasonló feltételezésekkel élnénk róluk, mint embertársainkról. Azt, hogy más emberek tudatos lények, nem azért tételezzük fel, mert bepillanthattunk elméjük múködésébe, hanem azért, mert a viselkedésük összeegyeztethetố ezzel a feltételezéssel. Ha a mesterséges intelligenciák is következetesen hasonló módon viselkednének, akkor hajlamosak lennénk gyökeresen megváltoztatni a róluk alkotott véleményünket is (ezt nevezi Dennett ,intencionális alapállásnak”), és elismernénk a jogaikat.

Az ember és a számítógép közötti interakciók fontosságának felismerése a jogi közösség részéról szükségszerú következményeket von magával az MI-kutatás területén belül is. Rodney Brooks azt írja a Hús-vér emberekés gépek: Hogyan fognak megváltostatni bennünket a robotok? (Flesh and Machines: How robots will change us?) címú könyvében, hogy a mesterséges intelligencia kutatásának úttörói, ezek a briliáns, kissé különc emberek hajlamosak az intelligenciát olyan tevékenységek segítségével definiálni, amelyeket ók maguk izgalmasnak találnak - ilyen lehet például egy jó sakkjátszma, valamely elvont matematikai teoréma bizonyítása vagy bonyolult szóalgebrai feladványok megoldása.

A kutatásokban több évtizeden keresztül a problémák absztrakt megközelítése dominált, mígnem az MI kutatói elkezdték jobban értékelni azt, amit az intelligencia banális oldalának nevezhetünk. Kiderült, hogy könnyebb olyan robotot tervezni, amely le tud gyốzni egy sakkvilágbajnokot, mint olyat, amely a fizikai világban múködóképes, vagyis fel tud menni egy lépcsôn, képes kikerülni a bútorokat és tájékozódni közöttük, vagy fel tud ismerni egy emberi arcot. Az ilyen készségek programozásakor felmerülő nehézségek váltáshoz vezettek az intelligencia meghatározásában. A Turing-teszten iskolázott kutatók közül sokan továbbra is hangsúlyozták a kommunikációs készségekkel bíró intelligencia megtervezésének fontosságát, ám egyúttal belátták azt is, hogy ez a kommunikáció nem korlátozódhat többé a fizikai és az intellektuális tartományokat elválasztó határvonalnak csak az egyik oldalára, amit a Turing-teszt képvisel. Nagyobb kihívást jelentett olyan gépek - úgynevezett „szociális robotok” - létrehozása, amelyek a valós világban képesek interakcióba lépni az emberekkel. Valószínú, hogy a jogaiért jelentkezố elsó jelölt nem az íróasztalunk alatt ülô Dell-modell valamilyen feljavított változata lesz, hanem a robotoknak ebbe a családjába fog tartozni.

A szociális robotok mozgalmában az MIT munkatársa, Rodney Brooks játszik vezetô szerepet, aki a „megtestesítés” (embodiment) és a „szituáltság” (situatedness) elvei alapján tervezi meg robotjait. Egy szituált robot „beágyazódik” a világba, és azzal nem elvont, hanem közvetlen úton érintkezik. Egy megtestesült robotnak „fizikai teste van, és tapasztalatokat szerez a világról [...] közvetlenül azokon a hatásokon keresztül, amelyeket a világ erre a testre gyakorol”. Ezek az elvek Brooksnak abból a meggyốzódéséból erednek, hogy fogalmi apparátusunk alapját a fizikai világban való létezésünk képezi. A robotok csak akkor kezdhetik oly módon megtapasztalni a világot, ahogy mi tesszüik, ha hasonló apparátussal látjuk el óket.*

* „Ezek az újfajta robotok a cél és a mozgás szimbolikus reprezentációi helyett az aktuális mozgás és a funkcionálisan definiált cél közötti különbség alapján múködnek. [...] A vezérlés a környezet és a robot együttes állapota alapján csupán engedélyezi, lehetôvé teszi a lehetséges viselkedések egyikét, a megvalósulás a test dolga. Az ehhez szükséges viselkedési repertoárt együtt alkotják a fizikai felépítés által lehetôvé tett mozgások, a motorosan tanult viselkedések és az ezekre épüló különbözố vezérlési módok - utóbbiak között szerepelhetnek különféle felderítési és közlekedési stratégiák vagy akár más robotok felé irányuló kontaktusteremtési eljárások" (Kampis György: Evolúciós pszichológia. Magyar Tudomány, 2002/1.) - A ford. 
Brooks véleménye szerint az emberek intuitív módon meg fogják érteni, hogy a testtel bíró robotokkal hogyan lehet interakcióba lépni, és a folyamatos kölcsönhatás segíteni fog a robotok „oktatásában”. Ahhoz, hogy a szociális robotok meggyớzố beszélgetôpartnereink, sốt talán akár értékes társaink is lehessenek, fel kell ruházni óket elegendő érzelmi intelligenciával, beleértve az emberi viselkedés megismerését és internalizálását is, és „személyiséggel” kell rendelkezniük, amit kommunikálni képesek a külsố világ felé.

Brooks acél- és szilíciummenazsériájában a leghíresebb szociális robot a Kismet nevú, preternaturális reakcióképességekkel bíró robottorzó, amelyet nemrégiben „nyugállományba helyeztek” az MIT múzeumában. Kismetet az 1990-es évek végén kifejezetten az emberekkel folytatandó interakcióra tervezte meg Cynthia Breazeal, aki akkor Brooks laboratóriumában végezte doktori tanulmányait, most pedig a robotikus élettel foglalkozó kutatócsoport igazgatója az MIT médialaboratóriumában. A robotot ellátták a kifejezóképesség eszközeivel: a normálisnál nagyobb szemekkel, szemöldökkel, amelyet kérdốn fel tud vonni vagy fenyegetốn összeráncolni, és az elsôsegélynyújtásnál használatos rugalmas ragasztószalagból kialakított piros ajkakkal, amelyek megnyerő mosolyra tudnak húzódni vagy elutasítóan merev kifejezést ölthetnek.

Kismetet úgy alkották meg, hogy utánozza azokat a közvetlen interakciókat, amelyek általában egy csecsemó és a gondozója között valósulnak meg. Breazeal fố meglátása az volt, hogy a csecsemók azért tanulnak, mert a felnőttek foglalkoznak velük, és oly módon kezdeményeznek kölcsönhatásokat, ami a felnốtteket arra készteti, hogy szociális teremtényekként kezeljék óket. A csecsemố nem veleszületett öntudattal vagy intencionalitással jön a világra, hanem csak késóbb fejleszti ki ezeket a képességeket. Ugyanígy „tanulta meg” óket Kismet is, aki fel tud ismerni egy emberi arcot, viszonozza a tekintetet és egyfajta „dialógusra” is képes: tudja, mikor nézzen félre és mikor nézzen határozottan valakinek a szemébe, mikor beszéljen és mikor hallgasson. Nem túl jó társalgó, mivel csupán artikulált gügyögések sorozatának kibocsátására képes, de különbséget tud tenni az eltérố hangmagasságok között, és ennek megfelelốen válaszol a saját hangjával és arckifejezésével.

Kismetet felruházták továbbá számos érzelmi és motivációs állapottal, amelyek a viselkedését alakítják, és amelyeket folyamatosan monitorozhat. Ha például egy darabig nincs módja társasági interakcióra, akkor „unatkozik”, és körülnéz a szobában, azt „remélve”, hogy magára tudja vonni valamilyen szociálisan interaktív lény figyelmét (a tekintetét természetesen magukra irányítják a mozgásban levô, valamint a színes felületú dolgok). Ha akkor éri valamilyen stimulus, amikor jó hangulatban van, akkor elégedetten gógicsél, ha viszont olyankor stimulálják, amikor fáradt, akkor bosszúsan felemeli az egyik szemöldökét. Egyszer egy kutató hiába próbálta magára vonni Kismet figyelmét, és elkeseredetten sóhajtozni kezdett: „Kismet nem szeret engem.”. Kismet ekkor hirtelen odafordította a fejét, belenézett a szemébe, és elkezdett gügyögni neki: felismerte a bánatot a hangjában, és megpróbálta vigasztalni.

Kismet természetesen igen távol áll a népszerú tudományos-fantasztikus filmek és regények többé-kevésbé antropomorf, járkáló és beszélgetố humanoidjaitól. Ám az, ami még csupán egy évtizeddel ezelốtt is futurisztikus álmodozásnak tûnt, ma jelentôs összegekkel finanszírozott kutatási projektek célterülete. Dallasban, a Texasi Egye- 
temen egy doktori tanulmányait végzô diák létrehozott egy olyan mesterséges hámfelületet, amelynek az elasztikussága megközelíti az emberi bôrét, és változatosabb arckifejezések elérését teszi lehetôvé. Az új robotbốr révén a robotok fájdalmat is érzékelhetnek. A súrített levegóvel mozgatott, elektroaktív polimerekból készült robotizmok segítségével meglepóen hajlékony és ruganyos robottáncosokat tudtak elôállítani. A robotok egyre inkább úgy fognak kinézni és úgy is fognak viselkedni, mint mi magunk.

Ez azért fontos, mert az emberekben erôs antropomorfizáló impulzusok múködnek, és ezeknek a manipulálása - az evolúció során kialakult és rögzült alapfelépítésünkból adódóan - mintegy „beprogramozott” érzelmeket válthat ki. Egy ilyen impulzusnak, illetve az általa arra a bánásmódra gyakorolt potenciális hatásnak az illusztrálására, ahogyan az MI-t kezeljük, az Edinburghi Egyetem informatikai intézetének egyik munkatársa, Chris Malcolm az Egyesült Királyságban közzétett egy hipotetikus mesét, amely arról szól, hogy egy fizikus azt az úgynevezett kreatív kihívást elé állítja egy robottervező elé, hogy készítsen „elpusztíthatatlan robotot”. A robotikus némi mesterkedés után elóáll egy kis bundás teremtménnyel, leteszi az asztalra, majd egy kalapácsot ad a fizikus kezébe, és felszólítja, hogy pusztítsa el. A robot ide-oda szökdécsel, de amikor a fizikus felemeli a kalapácsot, azonnal a hátára fordul, panaszosan nyögdécsel, és a rémülettól tágra nyílt szemekkel, rettegve néz fel üldözójére. A fizikus leteszi a kalapácsot. Az „elpusztíthatatlan robot” életben marad, mert hasznot húzott abból az emberi ösztönból, hogy a kisgyermekekre jellemző „,aranyos” vonásokat felmutató lényeket védeni kell. Az MI jogainak kérdése tehát így is feltehetố: Attól, hogy mi magunk nem vagyunk hajlandók lesújtani a kalapáccsal, mekkora lépést kell megtenni addig a követelésig, hogy ezt mások se tegyék meg?

Cynthia Breazeal legutóbbi teremtménye, amit a Stan Winston Stúdióval, Hollywood elsố számú automata szörnyetegeket elóállító múhelyével együttmúködve alkotott meg, figyelemre méltó mértékben hasonlít erre az elpusztíthatatlan robotra: Leonardo egy két és fél láb magas, bundás, teljesen automatikus múködésú tedimackó. Egyike a mostanáig elkészült legkifejezóbb szociális robotoknak: harminckét motor mozgatja az arcát, tud látni, hallani, beszélni és érezni. A leginkább figyelemre méltó tulajdonsága az, hogy képes elsajátítani bizonyos készségeket. Ezt az emberek közvetlen utánzásával teszi, amelyhez fel kell fognia a tanuló és a tanító közötti hasonlóságokat, továbbá közvetlen személyes interakciókon keresztül is tanul, ami megkívánja, hogy megfeleló módon jelezni tudja, megértette-e azt, amit kell, vagy zavarban van. Ezek a fejlemények képviselik a következô, Kismet szociabilitását meghaladó evolúciós lépcsốt, és talán elvezetnek egy olyan pontig, amelynél a robot már képes lesz olyasmit is nyújtani, ami emlékeztet a barátságra. Breazeal kijelentette: „Ez a végsố cél a szociális intelligencia kutatásában.”.

Testetlen „társaság” érzékeléséhez elegendő gyors látogatást tennünk bármelyik csevegốszobában az interneten. Ahhoz azonban, hogy beszélgetốtársainkhoz valamilyen szinten érzelmileg is kötôdni tudjunk, el kell képzelnünk, hogy valahol testi valójukban is jelen vannak. Breazeal kísérleteket végzett annak kimutatására, hogy az emberek mélyebb, intenzívebb érzelmi reakciókat mutatnak Leonardo iránt, ha az fizikailag is jelen van, mint amikor csupán kétdimenziós, nagy felbontású animációs képét látják egy számítógép képernyójén. 
A megtestesítés fontosságának jelentốs következményei lehetnek a jogok szempontjából is. Egy testetlen számítógép képességeit a teljesítményén keresztül mérjük. Akkor juthatunk arra a következtetésre, hogy a számítógép tudatos, tehát jogokat vagy privilégiumokat biztosíthatunk számára, ha ez a teljesítmény - legyen az akár egy remek sakkjátszma vagy egy meggyớzó beszélgetés - az emberéhez viszonyítva átlépi a funkcionális hasonlóság küszöbét. Ha azonban egy testtel bíró szociális robot esetében döntenénk úgy, hogy jogokat adunk neki, akkor ebbe valószínúleg éppen annyira belejátszanának a saját empatikus képességeink is, mint a robot belsó felépítésére vonatkozó feltételezéseink. Döntésünk nemcsak attól függene, hogy a robot valójában micsoda vagy minek tartjuk, hanem attól is, hogy mit vált ki belólünk.

Empátiánk vagy éppen önteltségünk, esetleg ösztönösen következetes erkölcsiségünk révén arra hajlunk, hogy olyan entitások számára kérjünk vagy adjunk bizonyos jogokat, amelyek hasonlítanak ránk, de megtagadjuk a jogokat azoktól a dolgoktól, amelyekról ez nem mondható el. Jelentốs mennyiségú bizonyíték szól például amellett, hogy a delfinek képesek felismerni önmagukat a tükörben - ez egyike az öntudat kulcstesztjeinek, és olyan képesség meglétére utal a delfineknél, ami rajtuk kívül csak a nagy emberszabású majmokra és az emberre jellemzô. Ám noha sokan javasolják, hogy a törvényes védelmet érdemlő tudatosság egyik alapvetơ kritériumaként az öntudatot kellene elfogadnunk, a delfinek nem élvezik ugyanazokat a törvény adta jogokat, mint a csimpánzok és a gorillák, amelyek fenotípusukat tekintve hasonlóbbak az emberekhez.

Az intelligens számítógépek tervezése - függetlenül attól, hogy a technológia milyen gyorsan fejlódik - teljes mértékig az ellenórzésünk alatt áll. Ugyanez mondható el arról a védelemrốl és azokról a jogokról is, amelyeket garantálunk számukra. Csak akkor fogunk létrehozni a társadalom által jogok biztosítására érdemesnek tartott robotokat, ha saját akaratunkból így döntünk. Nem kell tehát véletlenszerúen létrejövő Frankensteinektól tartanunk.

Még ha a mesterséges intelligenciával rendelkezô gépeknek nem is biztosítunk olyan jogokat, mint amelyeket a hipotetikus esküdtszék BINA48 számára megítélt volna, valamilyenfajta törvényes védelmet bizonyára nyújtani fogunk számukra, mert arra a belátásra fogunk jutni, hogy ezek az emberi zsenialitás és kreativitás csúcsteljesítményét képviselik, és az ember kivételességének nem a cáfolatát, hanem inkább a visszatükröződését látjuk majd bennük. Anne Foerst lutheránus lelkész és az MI szakértôje, aki teológiai konzultánsként közremúködött a Kismet-projektben, a szociális robotok kifejlesztésében az istenimádat egy típusát látja. Isten a gépben: amit a robotok tanítanak nekünk az emberiségról és Istenról (God in the Machine: What Robots Teach Us About Humanity and God) címú, megjelenés elótt álló könyvében ${ }^{4}$ elmondja, hogy a Brooks laboratóriumában általa tapasztaltak hogyan erősítették meg benne „az emberi rendszer hihetetlen bonyolultsága” iránti tiszteletet, ami ốt „Isten 'legmagasabb rendű' teremtô aktusának ünneplésére" késztette.

Az efféle ünnepléssel elôsegített védelem valószínúleg nem a jog nyelvén fog megfogalmazódni: Christopher Stone különféle rangsorokba állítható kategóriákat, illetve szempontrendszereket dolgozott ki az MI számára a jövóben biztosítandó „jogi

${ }^{4}$ 2005-ben megjelent. - A szerk. megjegyz. 
státus" meghatározására. Az egyik lehetốség az, hogy az MI-vel rendelkezó gépeket értékes kulturális produktumokként kezelhetnénk, mintegy „kiemelt státust” (landmark status) biztosítva számukra, bizonyos kikötésekkel a megórzésükre, illetve a lerombolásukra vonatkozólag. Modellnek választhatnánk továbbá a veszélyeztetett fajok védelmét szolgáló törvényt is, amely bizonyos állatfajok számára nem elidegeníthetetlen jogaik, hanem „a nemzet és az emberek szemében általuk képviselt esztétikai, ökológiai, történelmi, rekreációs és tudományos értékek" tekintetbevétele alapján nyújt védelmet. Alkalmazhatnánk utilitárius érveket is védelmük indokolására, hasonlóan ahhoz, ahogyan Kant igazolta az állatoknak járó védelem bizonyos formáit, vagy ahogyan Jefferson érvelt a rabszolgák védelmében: hivatkozhatunk arra a lehetôségre, hogy ha nem biztosítjuk ezt a védelmet, akkor egyesek - a robotok nem megfelelő kezelésének láttán - rosszul bánhatnak az emberekkel is.

Az MI-vel kapcsolatos jogi kérdésekról való gondolkodás mindezekben az esetekben oda vezet, hogy szembe kell néznünk számos általunk létrehozott törvényes küszöb és jogi demarkációs vonal meghatározatlanságával. Ez egyrészt kijózanító, másrészt hasznos is. Ha úgy döntünk, hogy megtagadjuk a jogokat az MI-tốl, ez valójában pozitív lépést jelentene. Ha pedig úgy döntünk, hogy jogokat követelünk az MI számára, mindig tudatában kell lennünk e döntésünk erkölcsi és jogi következményeinek.

Jogrendszerünk ,asimovizálása” még semmi esetre sem tekinthető a közeljövő feladatának. A számítógépeknek és robotoknak a szóbeli „dialóguskészségen” kívül még nagyon sok mindent meg kell tanulniuk tôlünk, hogy teljesebb mértékben emberivé váljanak. Ám az is igaz, hogy ugyanezen cél érdekében mi magunk is még sokat tanulhatunk tóllük. 